\title{
Effect of Colombian coal rank and its feeding technology on substitute natural gas production by entrained gasification
}

\author{
Efecto del rango de carbones colombianos y su tecnología de \\ alimentación en la producción de gas natural sustituto, mediante \\ gasificación en lecho arrastrado
}

Efeito da gama de carvões colombianos e sua tecnologia de
alimentação na produção de gás natural substituto, mediante
gaseificação em leito arrastado

Fecha de recepción: 03 de octubre de 2015

Fecha de aprobación: 10 de diciembre de 2015

\author{
Juan Fernando Pérez-Bayer* \\ Rolando Barrera-Zapata** \\ Carlos Alberto Salazar-Jiménez ${ }^{* * *}$
}

\begin{abstract}
The effect of coal rank (from sub-bituminous to semi-anthracite) and type of fuel feeding technology (slurry and dry) on the production of substitute natural gas (SNG) in entrained flow gasifiers is studied. Ten coals from important Colombian mines were selected. The process is modeled under thermochemical equilibrium using Aspen Plus, and its performance is evaluated in function of output parameters that include SNG heating value, Wobbe index, coal conversion efficiency, cold gas efficiency, process efficiency, global efficiency, and SNG production rate, among others. In descending order, the coal-to-SNG process improves energetically with the use of coals with: higher volatile-matter to fixed-carbon ratio, lower ash content, higher $\mathrm{C}+\mathrm{H} / \mathrm{O}$ ratio, and higher coal heating value. The overall energy efficiency of the slurry-feed technology (S-FT) to produce SNG by gasification is $17 \%$ higher than the dry-feed technology (D-FT), possibly as a consequence of the higher $\mathrm{CH}_{4}$ concentration in the syngas (around $7 \mathrm{vol}$. \%) when the coal is fed as aqueous slurry. As the simulated SNG meets the natural gas (NG) quality standards in Colombia, the substitute gaseous fuel could be directly transported through pipelines. Therefore, the coal-to-SNG process is a technically feasible and unconventional alternative for NG production.
\end{abstract}

Key words: Coal-SNG, Substitute natural gas, Coal rank, Entrained flow gasification, Coal feeding technology, Aspen plus.

\section{Resumen}

Presenta los resultados de un estudio del efecto del rango del carbón usado (desde subbituminoso hasta semiantracita) y de la tecnología de alimentación (seca o húmeda) sobre el proceso de producción de gas natural sustituto (GNS) en gasificadores de flujo arrastrado. Se analizaron diez carbones provenientes de importantes minas de Colombia. El proceso

* Ph.D. Universidad de Antioquia (Medellín-Antioquia, Colombia). jfernando.perez@udea.edu.co.

** Ph.D. Universidad de Antioquia (Medellín-Antioquia, Colombia). rolando.barrera@udea.edu.co.

*** M.Sc. Celsia S.A. ESP. (Barranquilla-Atlántico, Colombia). csalazar@celsia.com. 
de producción de GNS a partir de gasificación de carbón se modeló bajo equilibrio termoquímico en Aspen Plus. El rendimiento del proceso se evaluó en términos de parámetros de salida, que incluyen el poder calórico del GNS, el índice de Wobbe, la eficiencia de conversión de carbón, la eficiencia en frío, la eficiencia del proceso, la eficiencia global y la tasa de producción de GNS, entre otros. En orden descendente, el proceso carbón-GNS mejora energéticamente con el uso de carbones con alta relación material volátil/carbón fijo, bajo contenido de ceniza, alta relación $\mathrm{C}+\mathrm{H} / \mathrm{O}$ y alto valor calórico del carbón. La eficiencia energética global para la producción de GNS vía gasificación es $17 \%$ mayor para la tecnología de alimentación en húmedo con respecto a la tecnología de alimentación en seco; esto posiblemente se da por la mayor concentración de $\mathrm{CH}_{4}$ en el syngas (alrededor del 7\% vol.) cuando se usa alimentación en húmedo. El GNS simulado cumple los estándares de calidad de gas natural (GN) en Colombia; por lo tanto, el combustible gaseoso sustituto podría transportarse directamente por gasoductos. Por lo anterior, es técnicamente viable considerar el proceso carbón-GNS como una alternativa no convencional para la producción de GN.

Palabras clave: Carbón-GNS, Gas Natural Substituto, Rango de carbón, Gasificación en lecho arrastrado, Tecnología de alimentación del carbón, Aspen Plus.

\section{Resumo}

Apresenta os resultados de um estudo do efeito da gama do carvão usado (desde sub-betuminoso até semi-antracita) e da tecnologia de alimentação (seca ou úmida) sobre o processo de produção de gás natural substituto (GNS) em gaseificadores de fluxo arrastado. Analisaram-se dez carvões procedentes de importantes minas da Colômbia. O processo da produção de GNS a partir de gaseificação do carvão se modelou sob o equilíbrio termoquímico em Aspen Plus. O rendimento do processo avaliou-se em termos de parâmetros de saída, que incluem o poder calórico do GNS, o índice de Wobbe, a eficiência de conversão de carvão, a eficiência em frio, a eficiência do processo, a eficiência global e a taxa de produção de GNS, entre outros. Em ordem descendente, o processo carvão-GNS melhora energeticamente com o uso de carvões com alta relação material volátil/carvão fixo, baixo teor de cinza, alta relação $\mathrm{C}+\mathrm{H} / \mathrm{O}$ e alto valor calórico do carvão. $\mathrm{A}$ eficiência energética global para a produção de GNS via gaseificação é $17 \%$ maior para a tecnologia de alimentação em úmido com respeito à tecnologia de alimentação em seco; isto possivelmente acontece pela maior concentração de $\mathrm{CH} 4$ no syngas (ao redor de 7\% vol.) quando usa-se alimentação em úmido. O GNS simulado cumpre os padrões de qualidade de gás natural (GN) na Colômbia; portanto, o combustível gasoso substituto poderia transportar-se diretamente por gasodutos. Consequentemente, é tecnicamente viável considerar o processo carvão-GNS como uma alternativa não convencional para a produção de GN.

Palavras chave: Carvão-GNS, Gás Natural Substituto, Gama de carvão, Gaseificação em leito arrastado, Tecnologia de alimentação do carvão, Aspen plus.

\section{Nomenclature}

ASTM: American Society for Testing and Materials

CCE: Coal Conversion Efficiency (\%)

CGE: Cold gas efficiency (\%).

$(\mathrm{C}+\mathrm{H}) / \mathrm{O}:$ Carbon plus Hydrogen to Oxygen ratio

$\mathrm{C}_{\mathrm{n}} \mathrm{H}_{\mathrm{p}} \mathrm{O}_{\mathrm{p}} \mathrm{N}_{\mathrm{q}} \mathrm{S}_{\mathrm{r}}$ : Coal substitution formula

D-FT: Dry coal feeding technology

ER: Equivalence ratio (oxygen/coal)

$\mathrm{ER}_{\text {absoluty }}$ : Real oxygen/coal ratio

$\mathrm{ER}_{\text {sto }}^{\text {a }}$ Stoichiometric equivalence ratio (oxygen/coal)

GE: Global efficiency (\%)

$\mathrm{HHV}_{\mathrm{i}}$ : Higher heating value for specie $\mathrm{i}(\mathrm{kJ} / \mathrm{kg}$ or $\mathrm{kJ} /$ $\left.\mathrm{Nm}^{3}\right)$
IGCC: Integrated Gasification Combined Cycle

MMCFD: Million cubic feet per day

$\mathrm{M}$ : : Molecular weight for substance i $(\mathrm{kg} / \mathrm{kmol})$

$\dot{m}_{i}:$ mass flow $(\mathrm{kg} / \mathrm{h})$ for specie $\mathrm{i}$

NG: Natural Gas

PE: Process efficiency (\%)

$\rho:$ density

$\mathrm{R} / \mathrm{P}$ : reserves to production ratio (years)

S-FT: Slurry coal feeding technology (S-FT)

SNG: Synthetic or substitute natural gas

UPME: Colombia Mining and Energy Planning Unit

VM/FC: Volatile matter to fixed carbon ratio

WGSR: Water-gas shift reactor

WI: Woobe index $\left(\mathrm{MJ} / \mathrm{Nm}^{3}\right)$.

$\mathrm{X}_{\mathrm{i}}$ : Mass fraction of substance i $(\%)$

Cómo citar este artículo:

[1] J. F. Pérez-Bayer, R. Barrera-Zapata \& C. A. Salazar-Jiménez, "Effect of Colombian coal rank and its feeding technology on substitute natural gas production by entrained gasification", Fac. Ing., vol. 25 (41), pp. 41-53, ene.-abr. 2016. 


\section{INTRODUCTION}

According to the Colombian Mining and Energy Planning Unit (UPME), the NG consumption in the country will increase by around $4 \%$ per year until 1070 MMCFD (million cubic feet per day) in 2020, and then it will reach 1330 MMFCD by 2030 . Furthermore, the existing gas reserves and production reports in Colombia indicate that local demand of NG may be satisfied until 2019 [1]. In this context, it is necessary to search for alternatives to reduce NG future imports given its high share $(18.4 \%)$ on the primary energy consumption in the country [2]. Coal accounts for $70 \%$ of the proven fossil fuel reserves in the world, with a reserves-to-production ratio $(\mathrm{R} / \mathrm{P})$ of around 126 years. In addition, coal is a decentralized resource with lower cost than oil and gas [3]. In Colombia, which has the largest coal reserves in Latin America and is the fifth exporter of thermal coal in the world, coal production has experienced an annual average growth of $8 \%$ over the last decade [4], and nowadays the country exhibits a 91 years $\mathrm{R} / \mathrm{P}$ ratio. $\mathrm{On}$ the other hand, coal price has been declining from its 2011 peak of $100 \mathrm{USD} /$ ton [5]. Therefore, the energy outlook fosters the use of coal as an alternative fuel for shortages of NG in Colombia.

The quality of the coal, i.e., coal rank, reactivity, heating value, among others, may play a significant role on the efficiency of thermochemical processes [6]. ChengHsien et al. [7] studied the gasification of bituminous and sub-bituminous coals with petroleum coke in a fluidized reactor, and reported that the best results were reached with mixtures of 30\% sub-bituminous coal (high ash content) $+70 \%$ petroleum coke, and $50 \%$ bituminous coal (high moisture and volatile content) + $50 \%$ petroleum coke. Tomeczek and Gil [8] studied the hydrogasification in a fixed bed reactor, and found that the char from lignite was slightly more reactive than the char from sub-bituminous coal. Karcz and Porada [9] hydrogasified six coals with different rank, and reported that the mid-range coals produced the highest coal conversion rates. Lee et al. [10] determined the effect of four different bituminous coals in the SNG production by hydrogasification, finding that coal conversion is directly proportional to the temperature and pressure in the reactor; in addition, coal with the higher volatile content reached the higher conversion (48\%). Maurstad et al. [11] modeled an IGCC plant in Aspen Plus, using two technologies (Shell D-FT and ConocoPhillips S-FT) and five types of coal, and found that the thermal efficiency diminished with coal rank using S-FT. Yun et al. [12] evaluated the effect of nine types of coal on IGCC Korean power plants, recommending the selection of coals with low ash content, low sulfur content, high VM/FC ratio, and low coal slag viscosity. Gräbner and Meyer [13] analyzed the coal rank effect (standard and high-ash content coals) on the gasifier technology (Shell, Siemens, Texaco, ConocoPhillips and High Temperature Winkler), reporting that the higher exergy efficiencies were reached with ConocoPhillips (S-FT) and Shell (D-FT) using the standard coal. Kunze and Spliethoff [14] developed an Aspen Plus model to simulate a generic entrained-flow gasifier, specifically to analyze the effect of the fuel feed system (S-FT and D-FT) on the gasification process at 30 bar; a higher energy efficiency was found for D-FT $(83 \%)$ than for S-FT (72\%).

The literature review indicates, thence, that the effect of coal rank on the SNG production process by means of gasification in entrained-flow reactors has not yet been fully investigated.

The aim of this work is, therefore, to perform a detailed analysis on the coal-to-SNG process with ten different Colombian coal rank (from sub-bituminous to semianthracite, covering the whole range of coal produced in Colombia [5]) and different solid fuel feeding technologies to the gasifier (slurry and dry), using a thermo-equilibrium model as simulation tool [15]. The characterization of coal used is shown in Table I and corresponds to coal samples from mines located in different Colombian states: Cesar, Santander, Cundinamarca, Antioquia, and Cauca [16]. The gasification parameters analyzed include carbon conversion efficiency, cold gas efficiency, process and global energy efficiency, SNG heating value, and Wobbe Index. These parameters can be used to select coal and fuel feeding technology using optimization process criteria. Furthermore, the energy analysis described in this work contributes to assess global alternatives for the unconventional NG production. 


\section{TABLE I}

Chemical Characterization of SElected Colombian COAL

\begin{tabular}{|c|c|c|c|c|c|c|c|c|c|c|}
\hline \multicolumn{11}{|l|}{ Parameter / } \\
\hline Code & $\mathrm{C} 1$ & $\mathrm{C} 2$ & $\mathrm{C} 3$ & $\mathrm{C} 4$ & $\mathrm{C} 5$ & C6 & $\mathrm{C} 7$ & $\mathrm{C} 8$ & C9 & $\mathrm{C} 10$ \\
\hline \multicolumn{11}{|c|}{ Proximate analysis } \\
\hline VM & 31,84 & 8,83 & 45,89 & 33,18 & 33,42 & 21,9 & 11,22 & 38,59 & 46,36 & 45,53 \\
\hline $\mathrm{FC}$ & 58,35 & 85,2 & 47,61 & 54,49 & 49,74 & 59,99 & 70,63 & 48,22 & 48,65 & 46,77 \\
\hline Ashes & 9,81 & 5,97 & 6,5 & 12,33 & 16,84 & 18,11 & 18,15 & 13,19 & 4,99 & 7,7 \\
\hline Moisture (\%wt) & 1,14 & 4,3 & 19.05 & 2,49 & 3,12 & 8,81 & 3,43 & 5,05 & 3,41 & 10,35 \\
\hline \multicolumn{11}{|l|}{ Ultimate analysis ${ }^{i}$} \\
\hline $\mathrm{C}$ & 68,43 & 69,87 & 68,24 & 68,01 & 53,51 & 58,88 & 60,54 & 58,01 & 70,17 & 65,34 \\
\hline $\mathrm{H}$ & 4,90 & 3,68 & 4,9 & 5,00 & 4,77 & 4,25 & 3,50 & 5,00 & 5,56 & 5,66 \\
\hline $\mathrm{N}$ & 0,14 & 0,00 & 1,59 & 0,00 & 0,00 & 0,00 & 0,00 & 0,09 & 0,07 & 0,02 \\
\hline $\mathrm{O}$ & 15,64 & 19,63 & 17,41 & 13,77 & 24,09 & 17,36 & 16,71 & 22,90 & 17,46 & 20,89 \\
\hline $\mathrm{S}$ & 1,07 & 0,85 & 1,36 & 0,89 & 0,79 & 1,4 & 1,1 & 0,82 & 1,76 & 0,4 \\
\hline Ashes & 9,81 & 5,97 & 6,5 & 12,33 & 16,84 & 18,11 & 18,15 & 13,19 & 4,99 & 7,7 \\
\hline $\mathrm{HHV}^{\mathrm{i}}(\mathrm{kJ} / \mathrm{kg})$ & 32281 & 33879 & 27918 & 31115 & 29358 & 29258 & 28835 & 27749 & 32879 & 28160 \\
\hline
\end{tabular}

idry basis. Mines: C1, Alejandría-Cogua; C4, Trinidad-Sutatausa; C5, Trinidad-Siscuda; C9, San Francisco-Cajibío (highvolatile A bituminous); C8, San Francisco-Patía (highvolatile B bituminous); C10, Nechí-Amaga (high volatile C bituminous); C6, San Francisco-Palmar (médium volatile bituminous); C3, Bijao-Cordoba (sub-bituminous B); C2, Carboland; C7, San FranciscoCampo Alegre (semi-anthracite).

\section{Methodology}

\section{A. Model description and simulation details}

Figure 1 displays the model used to simulate coal-toSNG process. In the slurry-feed technology (S-FT) the coal is supplied as a mixture of coal and water to an entrained-flow gasifier. This model includes two reactors in series to simulate the gasification stage [15]. The dry-feed technology (D-FT) model, on the other hand, considers feeding dry coal and $\mathrm{CO}_{2}$ as gas carrier into the gasifier. The main stages of the process are comparable to the slurry-feed process taking into account specific differences in both gasification processes, i.e., the model for the D-FT considers just one reactor to simulate the gasification stage [15].

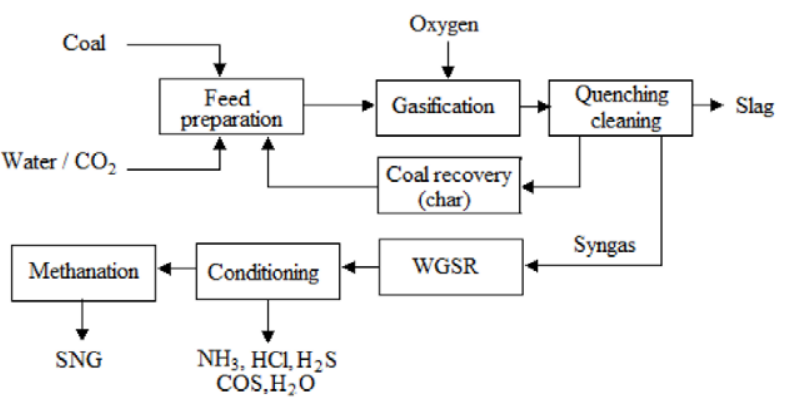

Fig. 1. Block diagram of the coal-to-SNG production by gasification. Adapted from Barrera et al. [15].

The main assumptions in the Aspen Plus models are: steady-state, chemical equilibrium approach (Gibbs free energy minimization), adiabatic gasification, and complete transformation of coal ash into slag. A detailed description of the model implemented in Aspen Plus to simulate SNG production by means of coal gasification, as well as the model validation, is presented elsewhere [15]. The relationships used in the calculation of the energy parameters to characterize SNG production by coal gasification are presented in Table II [5]. 


\section{TABLE II}

RELATIONSHIPS FOR THE CALCULATION OF COAL PROCESSING ENERGY PARAMETERS

\begin{tabular}{|c|c|}
\hline Parameter & Relationship \\
\hline $\begin{array}{l}\text { Equivalence Ratio } \\
\text { (ER) }\end{array}$ & $E R=\frac{E R_{\text {absolut }}}{E R_{\text {stq }}}=\frac{\left(\dot{m}_{O 2} / \dot{m}_{\text {Coal }}\right)}{E R_{\text {stq }}}$ \\
\hline
\end{tabular}

Stoichiometric

Equivalence Ratio

$\left(\mathrm{ER}_{\mathrm{stq}}\right)$

$$
E R_{s t q}=\frac{\left(n+\frac{m}{4}+\frac{r}{2}-\frac{p}{2}\right) m o l \cdot M_{O 2}\left(\frac{\mathrm{kg}}{\mathrm{kmol}}\right)}{1 \mathrm{~mol} \cdot M_{\text {coal }}\left(\frac{\mathrm{kg}}{\mathrm{kmol}}\right)}
$$

Considering the stoichiometric reaction:

$\mathrm{C}_{n} \mathrm{H}_{m} \mathrm{O}_{p} \mathrm{~N}_{q} \mathrm{~S}_{r}+\varphi \mathrm{O}_{2} \rightarrow a \mathrm{CO}_{2}+b \mathrm{H}_{2} \mathrm{O}+d \mathrm{~N}_{2}+f \mathrm{SO}_{2}$

where $\varphi=n+\frac{m}{4}+\frac{r}{2}-\frac{p}{2}$

Coal Conversion

Efficiency $\quad\left(C C E, \quad C C E=\frac{\dot{m}_{S N G}}{\dot{m}_{\text {coal }}} \times 100\right.$

Cold Gas

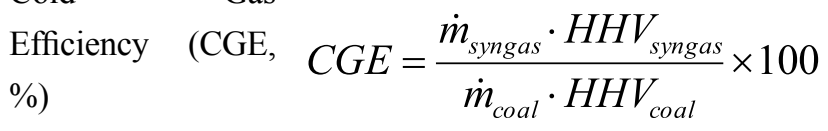

$V_{\text {syngas }}=\sum_{i} X_{i} \cdot H_{H} \quad$ where $\quad i=C O, \mathrm{CH}_{4}, \mathrm{H}_{2}, \mathrm{C}_{2} \mathrm{H}_{4}, \mathrm{C}_{6} \mathrm{H}_{6}, \mathrm{H}_{2} \mathrm{~S}$,

Process Efficiency

(PE, \%)

$P E=\frac{\dot{m}_{S N G} \cdot H H V_{S N G}}{\dot{m}_{\text {syngas }} \cdot H H V_{\text {syngas }}} \times 100$

SNG higher heating value, $\left(\mathrm{HHV}_{\mathrm{SNG}}\right)$

$H H V_{S N G}=\sum_{j} X_{j} \cdot H H V_{j} \quad$ where $\quad j=C O, \mathrm{CH}_{4}, \mathrm{H}_{2}$

Global efficiency

(GE, \%)

$G E=\frac{\dot{m}_{S N G} \cdot H H V_{S N G}}{\dot{m}_{\text {coal }} \cdot H H V_{\text {coal }}} \times 100=C G E \cdot P E$

Wobbe Index, WI

$\left(\mathrm{MJ} / \mathrm{Nm}^{3}\right)$

$W I=\frac{H H V_{S N G}}{\sqrt{\frac{\rho_{S N G}}{\rho_{\text {air }}}}}$ With $\rho$ estimated at $\mathrm{P}=1 \mathrm{~atm}, \mathrm{~T}=15^{\circ} \mathrm{C}$. 
In order to evaluate the effect of coal-rank (10 different coals) and fuel feeding technology (2 different feeding technologies) on the coal-to-SNG process, a simulation is conducted under constant ER. The ER for S-FT was set at 0.25, while ER for D-FT was set at 0.33 . Therefore, the oxygen/carbon ratio ranges from 0.62 to 0.78 for the simulated technologies and coals. The ER values used in this work were set according to real gasification conditions (real equivalence ratios) described in technical reports available in the literature for both technologies [11, 17-19].

The coal mass flow rate in simulations was fixed at $250 \mathrm{t} / \mathrm{h}$ for both feeding technologies, since typical suppliers have gasifiers with a coal processing capacity around 125 ton $/ \mathrm{h}$. Moreover, our goal is to simulate the production of at least 80 MMCFD of SNG to make the project feasible in Colombia [15]. Thereby, it is considered that the coal-to-SNG plant will use two gasifiers operating in parallel. The operating conditions used to simulate both feeding technologies in Aspen Plus are presented in Tables III and IV.
The oxygen mass flow rate refers to the gasifying agent fed to the process to achieve the desired ER for each coal rank (composition) and feeding technology, see Table III. The gasifier temperatures are estimated by the model as a function of the input parameters. The slurry-feed gasifier is modeled with two reaction stages (partial oxidation and devolatilization); therefore, two temperatures associated to each stage are calculated. The dry-feed reactor is modeled as a single reaction step. The steam mass flow rate is the amount of water required in the water gas shift reactor (WGSR) to adjust the syngas molar ratio to $\mathrm{H}_{2} / \mathrm{CO}=$ 3.0, which allows to reach the maximum $\mathrm{CH}_{4}$ yields in the methanation reactor; the steam mass flow rate was estimated with a sensitivity analysis in Aspen Plus [15]. The fixed operating conditions are shown in Table IV for both feeding technologies, regardless of the coal type. The as-received-coal to water ratio in the slurry was defined as 70/30 (mass \%) for all simulations. The $\mathrm{CO}_{2}$ mass flow rate (carrier gas) for the dry-feed gasifier was constant for all simulations. Pressure and temperature in the WGSR, as well as in the methanation reactor were constant and were taken from the literature [15].

\section{TABLE III}

OPERATING CONDITIONS USED IN SIMULATIONS CONDUCTED TO STUDY THE EFFECT OF THE TYPE COAL

\begin{tabular}{lllllllllll}
\hline & C1 & C2 & C3 & C4 & C5 & C6 & C7 & C8 & C9 & C10 \\
\hline S-FT, ER $=0.25$ & & & & & & & & & & \\
O mass flow (ton/h) & 142,9 & 130,3 & 136,1 & 147,9 & 117,5 & 132,7 & 132,1 & 123,7 & 140,7 & 134,2 \\
Tgasifier 1 $\left({ }^{\circ} \mathrm{C}\right)^{*}$ & 1322 & 1241 & 1439 & 1409 & 1301 & 1503 & 1482 & 1298 & 1222 & 1309 \\
Tgasifier 2 $\left({ }^{\circ} \mathrm{C}\right)^{*}$ & 908 & 883 & 893 & 920 & 876 & 911 & 916 & 879 & 890 & 883 \\
Steam to WGSR (ton/h) & 124,5 & 135,0 & 66,5 & 117,5 & 62,2 & 74,0 & 100,5 & 69,3 & 111,2 & 73,2 \\
\hline D-FT, ER = 0.33 & & & & & & & & & & \\
O mass flow (ton/h) & 188,7 & 171,9 & 179,7 & 195,3 & 155,2 & 175,2 & 174,5 & 163,3 & 185,8 & 177,2 \\
Tgasifier $\left({ }^{\circ} \mathrm{C}\right)^{*}$ & 1336 & 1217 & 1259 & 1410 & 1360 & 1495 & 1522 & 1318 & 1199 & 1230 \\
Steam to WGSR (ton/h) & 200,4 & 209,8 & 199,7 & 199,1 & 147,5 & 169,9 & 178,2 & 162,0 & 201,6 & 183,5 \\
\hline
\end{tabular}

* Operating temperature estimated from simulations. 
TABLE IV

OPERATING CONDITIONS USED IN SIMULATIONS

CONDUCTED TO STUDY THE EFFECT OF THE

FEEDING TECHNOLOGY

\begin{tabular}{lll}
\hline \multirow{2}{*}{ Operation condition } & \multicolumn{2}{l}{ Feeding technology } \\
& Slurry & Dry \\
\hline Coal mass flow (ton/h) & 250,0 & 250,0 \\
Water mass flow (ton/h) & 107,14 & -- \\
$\mathrm{CO}_{2}$ mass flow (ton/h) & -- & 153,23 \\
Pressure gasifier 1 (bar) & 50 & 50 \\
Pressure gasifier 2 (bar) & 50 & -- \\
Pressure WGSR (bar) & 49 & 49 \\
Temperature WGSR $\left({ }^{\circ} \mathrm{C}\right)$ & 250 & 250 \\
Pressure methanation $($ bar $)$ & 42 & 42 \\
Temperature methanation $\left({ }^{\circ} \mathrm{C}\right)$ & 350 & 350 \\
\hline
\end{tabular}

\section{RESULTS AND DISCUSSION}

\section{A. Coal gasification process (syngas production)}

The main energy parameters of the coal gasification process are shown in Figure 2. The $\mathrm{HHV}_{\text {syngas }}$, cold gas efficiency (CGE), and syngas mass flow rate are presented as a function of the ultimate analysis $\left(\mathrm{C}+\mathrm{H} / \mathrm{O}\right.$ ratio), $\mathrm{HHV}_{\text {coal }}$, and proximate analysis (VM/FC ratio), for all coal types and feeding technologies. It is observed that $\mathrm{HHV}_{\text {syngas }}$ ranges from 9 to $12 \mathrm{MJ} / \mathrm{Nm}^{3}$, Figure $2 \mathrm{a}$ and $2 \mathrm{~b}$, the higher values corresponding to slurry-feed gasification due to the higher concentration of combustible gases $\left(\mathrm{H}_{2}\right.$ and $\mathrm{CH}_{4}$ ) in the syngas; in fact, as S-FT operates with lower ER than D-FT the formation of combustible gases is favored. The $\mathrm{HHV}_{\text {syngas }}$ increases with $(\mathrm{C}+\mathrm{H}) / \mathrm{O}$ ratio and $\mathrm{HHV}_{\text {coal }}$, because the chemical equilibrium of the reactions involved in the production of combustible gases $\left(\mathrm{C}+\mathrm{H}_{2} \mathrm{O}\right.$ ó $\mathrm{CO}+\mathrm{H}_{2}, \mathrm{C}+2 \mathrm{H}_{2}$ ó $\mathrm{CH}_{4}$, and $\mathrm{CH}_{4}+\mathrm{H}_{2} \mathrm{O}$ ó $\mathrm{CO}+3 \mathrm{H}_{2}$ ) is favored by increasing $\mathrm{C}$ and/or $\mathrm{H}$ and by decreasing $\mathrm{O}$. According to Longanbach et al. [17], the higher concentration of $\mathrm{H}_{2}$ and $\mathrm{CH}_{4}$ is related to the higher concentration of reactive components such as $\mathrm{C}, \mathrm{H}$ and steam. On the other hand, Özturk et al. [19] found that the gasification exergy efficiency diminishes with higher oxygen content in the coal, which leads to a decrease of the content of combutible gases in the syngas. In this work similar results were observed (Figure 2a and 2b). Therefore, it is concluded that coals with higher heating value or higher $(\mathrm{C}+\mathrm{H}) / \mathrm{O}$ ratio produce a syngas with higher energy density $\left(\mathrm{HHV}_{\text {syngas }}\right)$ : $\mathrm{C} 1, \mathrm{C} 2, \mathrm{C} 4$ and $\mathrm{C} 9$ were found to be the raw materials that produce syngas with the highest $\mathrm{HHV}_{\text {syngas }}$, which is related both to the higher $\mathrm{C}$ and $\mathrm{H}$ content and lower oxygen content (Table 1), and to the larger $\mathrm{HHV}_{\text {coal }}$.

CGE varies between $68 \%$ and $84 \%$, Figure 2 c, with a slight trend to improve with the elemental coal composition $(\mathrm{C}+\mathrm{H}) / \mathrm{O}$. However, there are no significant differences between feeding technologies (slurry or dry). On the other hand, an increase in CGE with VM/FC ratio is noticed (see Figure 2d), which could be ascribed to the increase in syngas flow rate with higher VM content in the solid fuel (Figure 2e).

The improvement of gasification parameters with $\mathrm{VM}$ is a consequence of the higher coal conversion and reactivity with the increase in volatile matter [16]. Therefore, there is a raise in the amount of volatile compounds released in the pyrolysis stage which leads to lower amount of char to react in further reaction stages, aspects that favor the gasification process $[10$, 20].

In regard to the feeding technology, S-FT achieves higherCGE values, around 3\% larger than D-FT(Figure $2 \mathrm{c}$ and $2 \mathrm{~d}$ ). This slight variation in efficiency is due to the higher concentration of CO produced by the D-FT. In general, CGE values are comparable in both feeding technologies. Notwithstanding, the composition of the syngas varies with feeding technology, which is of great relevance for the performance of the global process when further processing units are considered (i.e., WGSR and methanation).

The concentration of gaseous fuels increases with $\mathrm{HHV}_{\text {coal }}$, Figure 3a. Syngas with higher $\mathrm{CH}_{4}$ content and lower $\mathrm{CO} / \mathrm{H}_{2}$ molar ratio is desired for further methanation process $[10,21]$, see Figure $3 a$ and $3 b$, because of the lower amount of $\mathrm{CO}$ required to shift to $\mathrm{H}_{2}$ in the water-gas shift reactor to obtain the $\mathrm{H}_{2}$ / $\mathrm{CO}$ molar ratio (3.0) needed in the methanation reaction $\left(\mathrm{CO}+3 \mathrm{H}_{2}\right.$ ó $\left.\mathrm{CH}_{4}+\mathrm{H}_{2} \mathrm{O}\right)$. Moreover, the lower $\mathrm{CO} / \mathrm{H}_{2}$ molar ratio reduces the carbon losses due to $\mathrm{CO}_{2}$ formation in the WGSR $\left(\mathrm{CO}+\mathrm{H}_{2} \mathrm{O}\right.$ ó $\left.\mathrm{CO}_{2}+\mathrm{H}_{2}\right)$. Therefore, S-FT requires around $65 \%$ of the syngas produced reacting with water in the WGSR, while the D-FT requires to react the $90 \%$ of the syngas in the WGSR. 


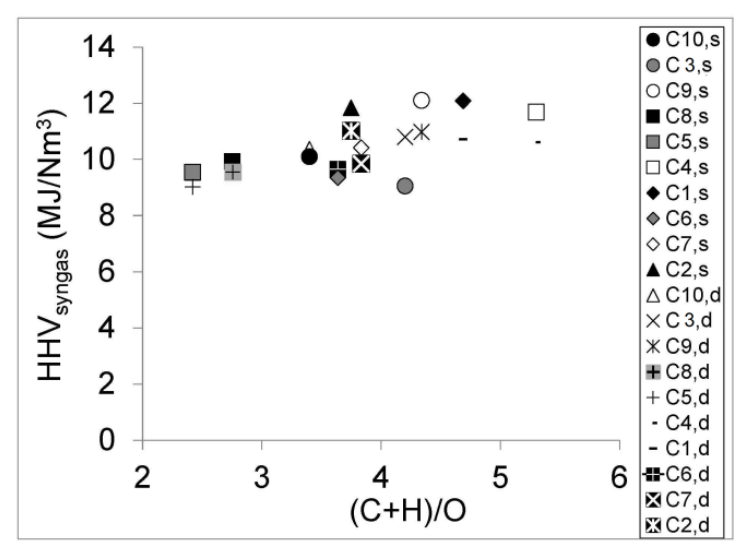

a) Effect of $(\mathrm{C}+\mathrm{H} / \mathrm{O})_{\text {coal }}$ in $\mathrm{HHV}_{\text {syngas }}$

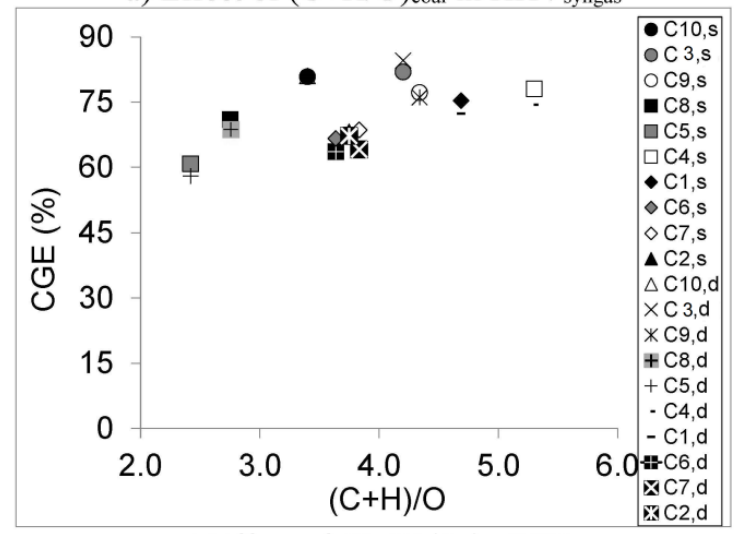

c) Effect of $(\mathrm{C}+\mathrm{H}) / \mathrm{O}$ in $\mathrm{CGE}$

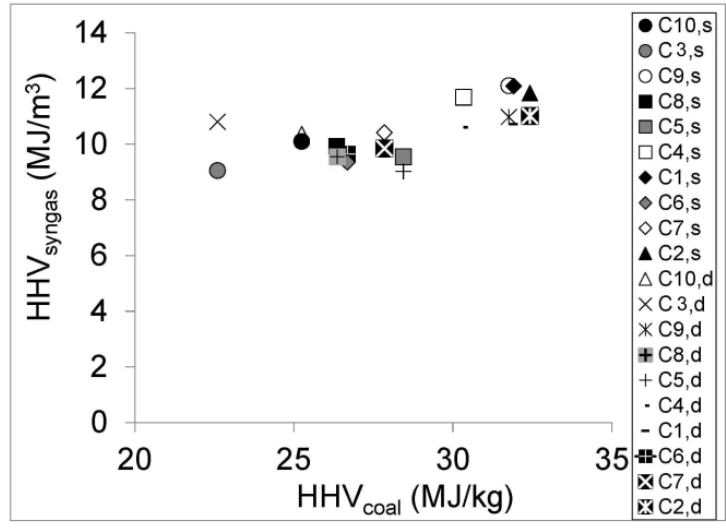

b) Effect of $\mathrm{HHV}_{\text {coal }}$ in $\mathrm{HHV}_{\text {syngas }}$

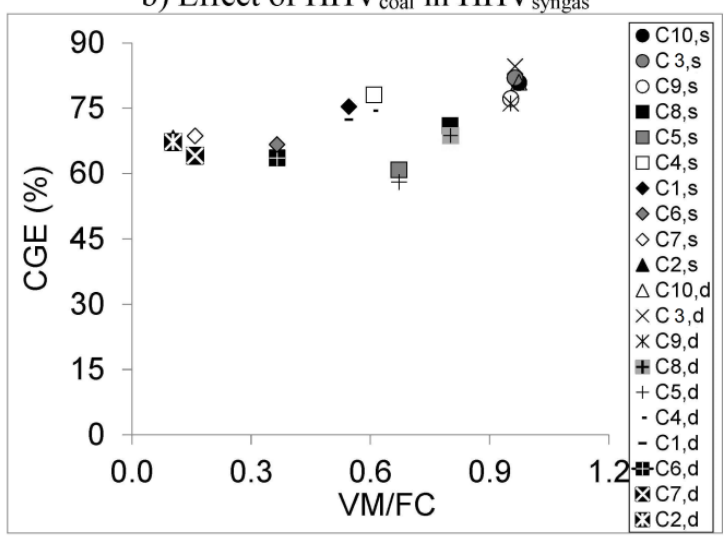

d) Effect of VM/CF in CGE

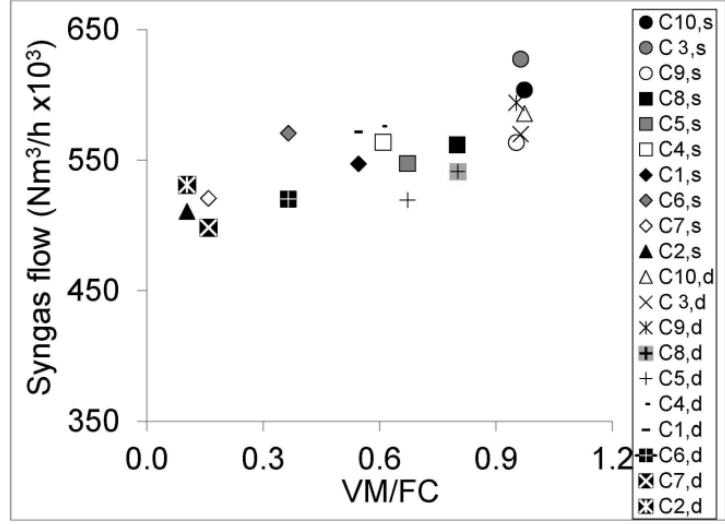

e) Effect of $V M / C F$ in the syngas flow

Fig. 2. Effect of type of coal and fuel feeding technology (slurry (s) and dry (d)) on coal gasification process.

\section{B. SNG production process (transformation of syngas to $S N G$ )}

The feeding technology and type of coal do not have a significant effect on the simulated SNG methane content (average 98.5 vol. \%), $\mathrm{HHV}_{\mathrm{SNG}}$ (average 39.3 $\mathrm{MJ} / \mathrm{m}^{3}$ ) and WI (average $52.9 \mathrm{MJ} / \mathrm{m}^{3}$ ) at the outlet of the process. SNG yield at the outlet of the process is quite similar for both technologies and all types of coal, because in every case the molar ratio $\mathrm{H}_{2} / \mathrm{CO}$ in the syngas is adjusted to a fixed value of 3.0 prior to the methanation stage. It can be concluded that SNG produced in all scenarios meets the NG quality standards of Colombia (i.e., $35.4 \mathrm{MJ} / \mathrm{m}^{3}<\mathrm{HHV}_{\mathrm{NG}}$ $\left.<42.8 \mathrm{MJ} / \mathrm{m}^{3}, 47.7 \mathrm{MJ} / \mathrm{m}^{3}<\mathrm{WI}_{\mathrm{NG}}<52.7 \mathrm{MJ} / \mathrm{m}^{3}\right)$, required for being directly transported by pipeline [22]. 


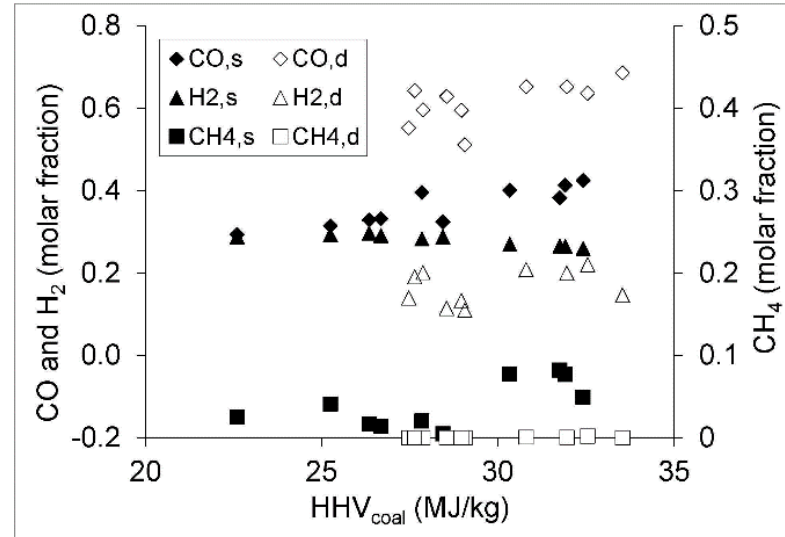

a) Gaseous combustible species in the syngas

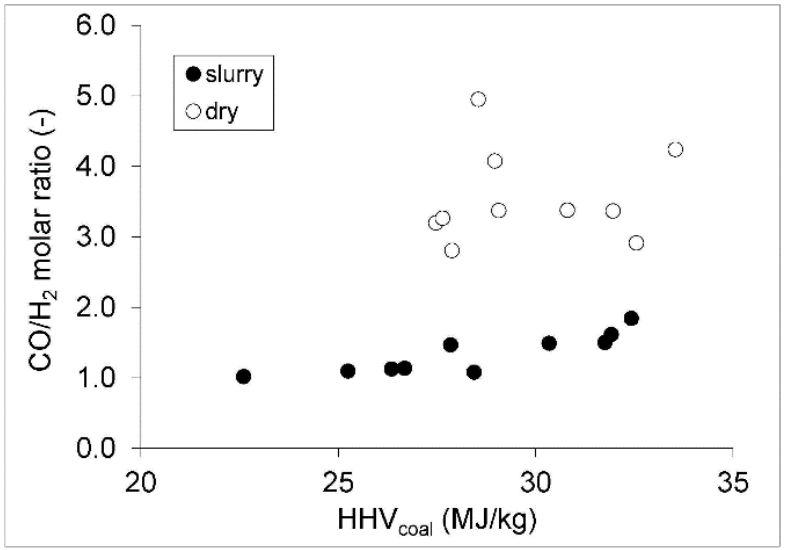

b) Molar ratio $\mathrm{CO} / \mathrm{H}_{2}$ of the syngas

Fig. 3.Syngas composition as function of coal-type $\left(\mathrm{HHV}_{\text {coal }}\right)$ for slurry (s) and dry (d) fuel feeding technologies.

The energy parameters that characterize the SNG production process are shown in Figure 4. In particular, the effect of coal type, i.e., ultimate analysis $(\mathrm{C}+\mathrm{H} / \mathrm{O}$ ratio), proximate analysis $\left(\mathrm{VM} / \mathrm{FC}\right.$ ratio), $\mathrm{HHV}_{\text {coal }}$ and the effect of feeding technology, on PE, GE and CCE are analyzed. No clear relationship is observed between coal type and PE (i.e., SNG energy/syngas energy). This behavior is expected because the coal characterization is not directly involved in the $\mathrm{PE}$ calculation (Eq. (5)). Even when coal characterization should affect the $\mathrm{HHV}_{\mathrm{SNG}}$ and the $\mathrm{HHV}_{\text {syngas }}$, no clear trends are observed (see Figure $4 \mathrm{a}$ and $4 \mathrm{~b}$ ). However, the feeding technology has a significant effect: PE of S-FT is $17 \%$ higher than that of D-FT, what could be attributed to the higher concentration of $\mathrm{CH}_{4}$ (average of 7 vol.\%) and $\mathrm{H}_{2}$ in the syngas, which translates into diminishing coal losses by $\mathrm{CO}_{2}$ formation in the WGSR [10]. Additionally, according to the real operating conditions reported in the literature $[11,17-$ 19], which were used in the simulations, the ER of the slurry process is $24 \%$ lower than for the dry process. The lower value in the former is a consequence of the two stages in the slurry gasifier, which results in higher concentration of gaseous fuel $\left(\mathrm{H}_{2}\right.$ and $\left.\mathrm{CH}_{4}\right)$ in the syngas; it is worth stressing that these two gases are of paramount importance for the further methanation process [23]. A clear relationship between global efficiency (i.e., SNG energy/coal energy ratio) and coal type is observed in Figure 4c and 4d. Formation of gaseous fuels is favored by increasing the $(\mathrm{C}+\mathrm{H})$ mass concentration in the coal. Therefore, $\mathrm{HHV}_{\text {s }}$ increases (Figure 4c) thus increasing the SNG production.

Regarding the proximate analysis, an increase of GE with $\mathrm{VM} / \mathrm{FC}$ ratio is observed, due to the higher syngas production associated with the volatile matter content (Figure 4d): the more reactive the coal (higher VM/FC ratio), the larger the process GE because of the higher conversion rate of coal [10,20]. Longanbach et al. [17] found similar results, stressing the higher reactivity associated with low rank coals and its positive effect on $\mathrm{H}_{2}$ production by means of gasification processes. 


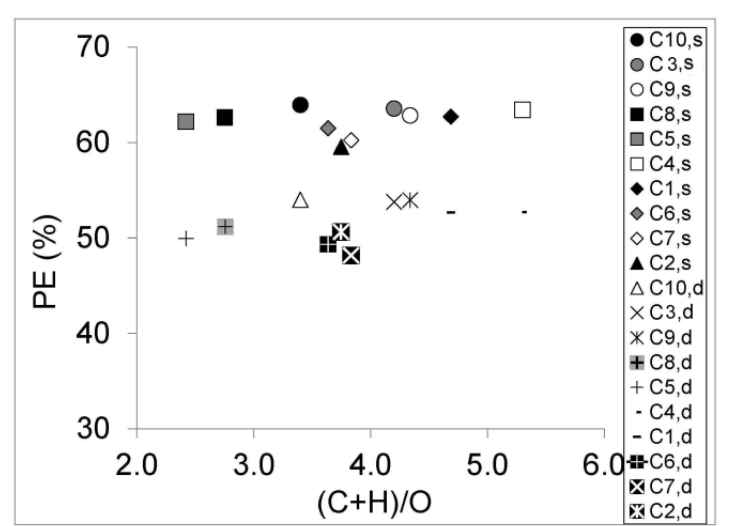

a) Effect of $(\mathrm{C}+\mathrm{H}) / \mathrm{O}$ ration in $\mathrm{PE}$

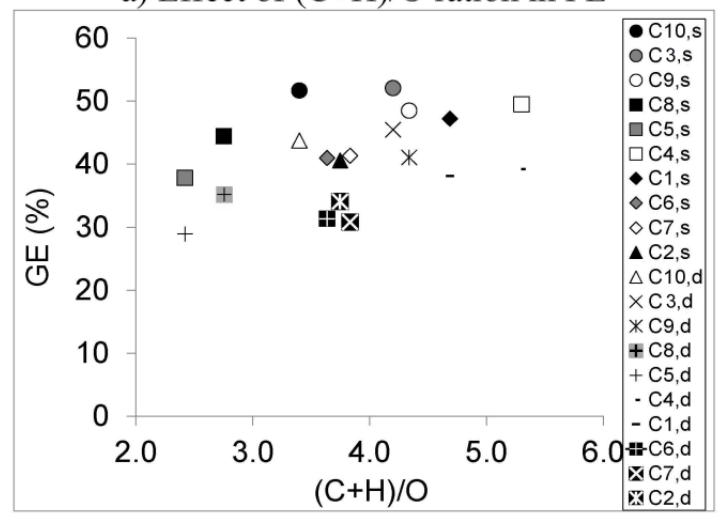

c) Effect of $(\mathrm{C}+\mathrm{H}) / \mathrm{O}$ in $\mathrm{GE}$

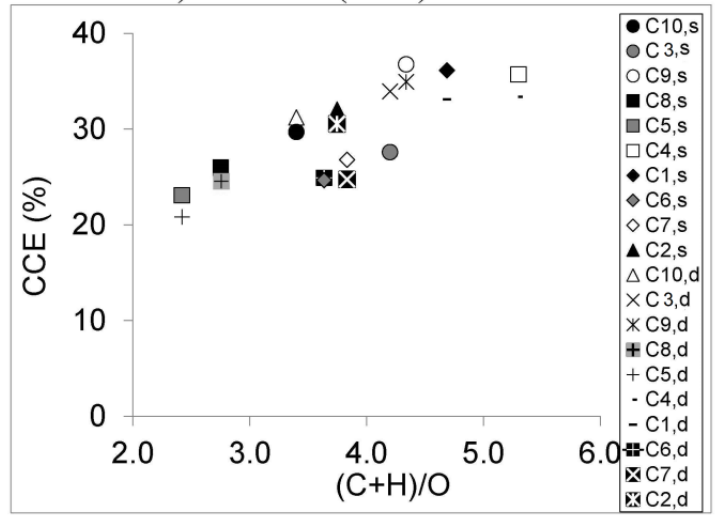

e) Effect of $(\mathrm{C}+\mathrm{H}) / \mathrm{O}$ in $\mathrm{CCE}$

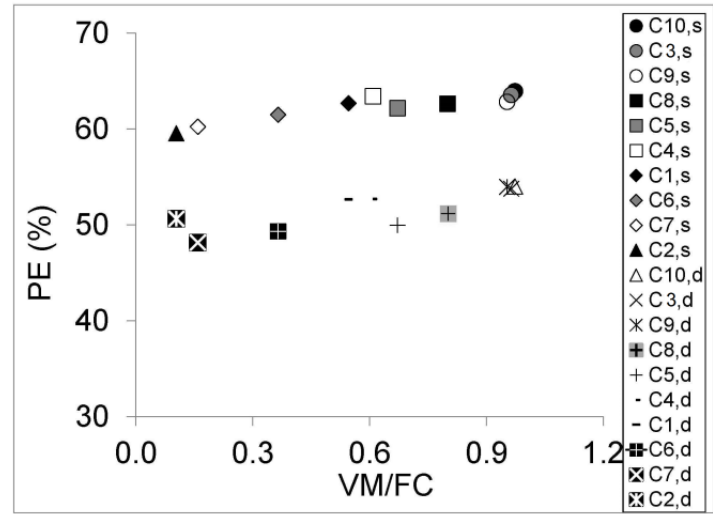

b) Effect of VM/FC in PE

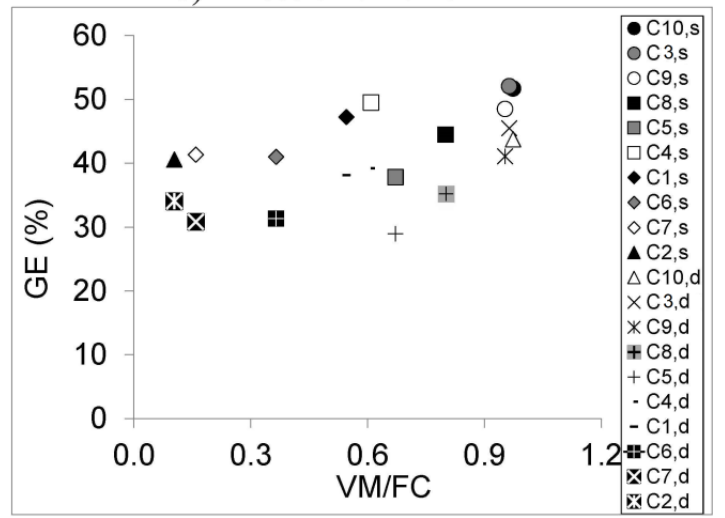

d) Effect of VM/FC in GE

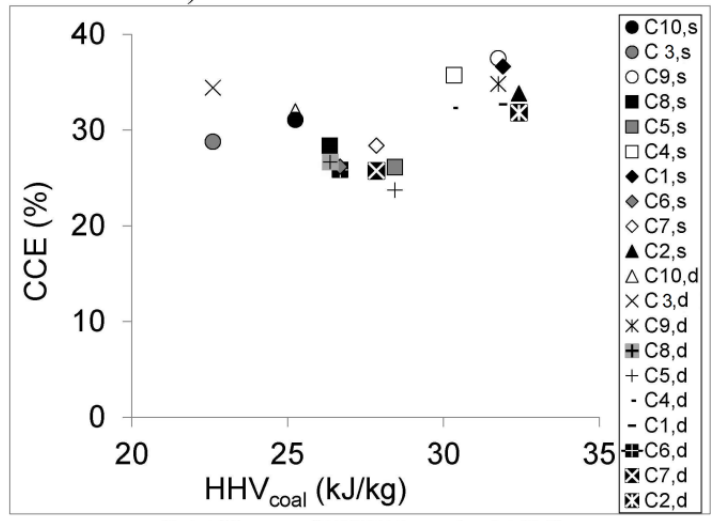

f) Effect of $\mathrm{HHV}_{\text {coal }}$ in ECC

Fig. 4. Effect of coal-type and fuel feeding technology [slurry (s) and dry (d)] on energy parameters of coal-to-SNG production process by entrained gasification.

Concerning the coal-to-SNG conversion efficiency (Figure $4 \mathrm{e}$ and $4 \mathrm{f}$ ), the slurry process reaches higher CCE (around 7\%) than D-FT, which could be traced to the operating conditions of the technologies: the slurry ER is 0.25 , two reaction stages and oxygen-steam as gasifying agent; while the dry gasification ER is 0.33 , one reaction step and oxygen- $\mathrm{CO}_{2}$ as gasifying agent. The difference of ER and gasifying agent leads to higher methane content (average of 7 vol. \%) in the syngas produced with S-FT, while the dry gasification does not produce $\mathrm{CH}_{4}$ in the syngas. Furthermore, $\mathrm{CH}_{4}$ concentration in the syngas affects directly the production of SNG because this species does not react in the WGSR (differently from CO, which reacts with $\mathrm{H}_{2} \mathrm{O}$ to produce $\mathrm{H}_{2}$ and $\mathrm{CO}_{2}$ ); therefore, the SNG production capacity increases in the process by lower losses of coal as $\mathrm{CO}_{2}[10,21]$. 


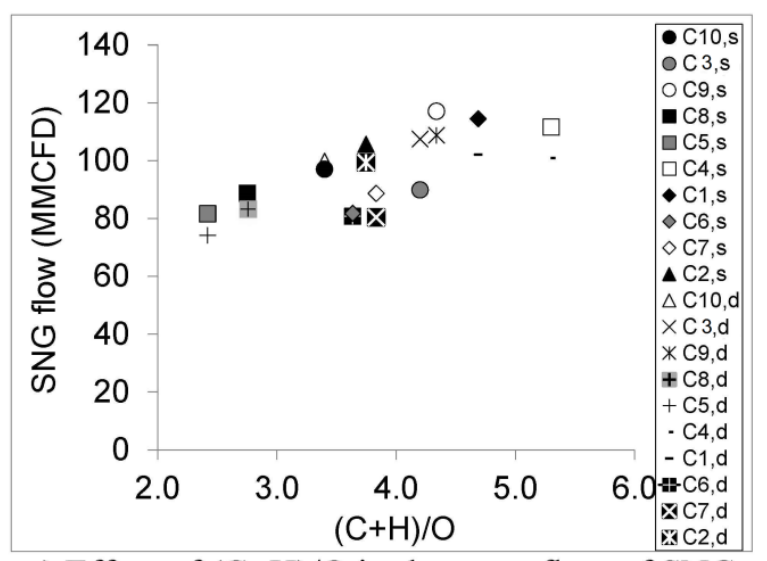

a) Effect of $(\mathrm{C}+\mathrm{H}) / \mathrm{O}$ in the mass flow of $\mathrm{SNG}$

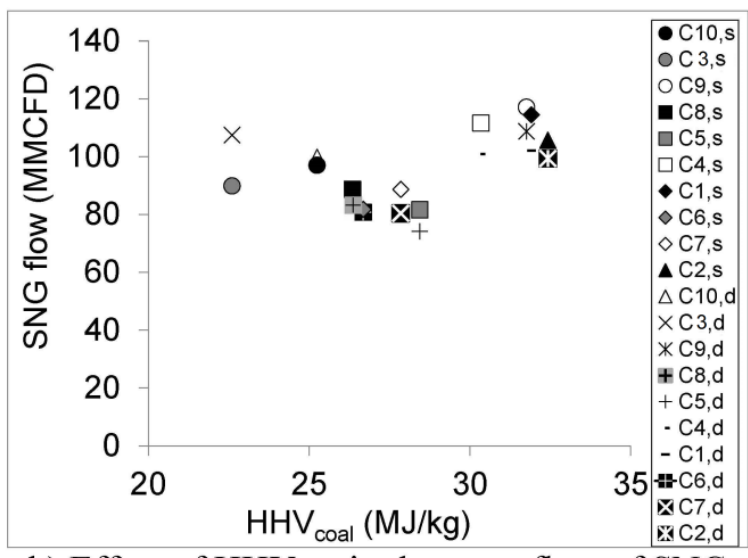

b) Effect of $\mathrm{HHV}_{\text {coal }}$ in the mass flow of SNG

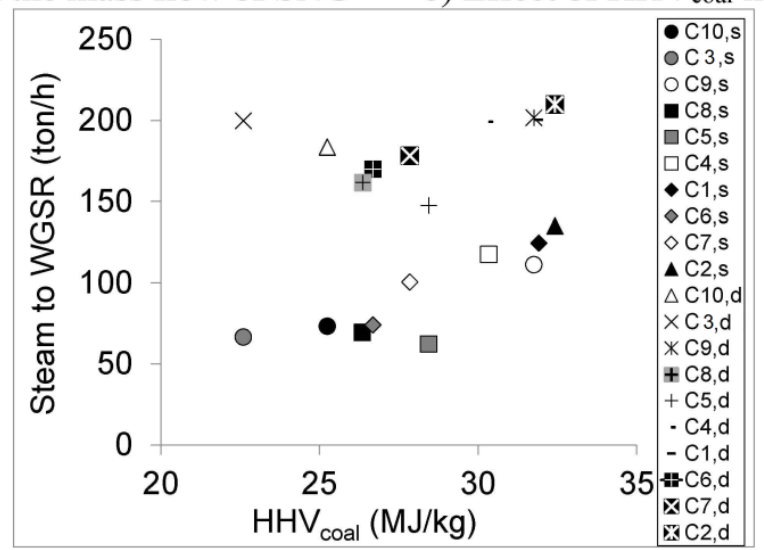

c) Effect of $\mathrm{HHV}_{\text {coal }}$ in the steam mass flow for the WGSR

FiG. 5. Effect of coal-type andfuel feeding technology [slurry (s) and dry (d)] in the mass flow of SNG produced and steam required in the process.

Similarly, CCE is affected by the coal type, i.e., ultimate analysis, and the coal heating value. As described previously, increasing the reactive components in the coal (i.e., $(\mathrm{C}+\mathrm{H})$ or $\left.\mathrm{HHV}_{\text {coal }}\right)$, the amount of gaseous fuels in the syngas is favored. Therefore, CCE increases due to the higher syngas availability to produce SNG. However, the C5 and C6 bituminous coals reach lower GE and CCE despite their high VM, due to their higher ash contents, $16.8 \%$ and $18.1 \%$, respectively. Moreover, low yields reached by $\mathrm{C} 7$ coal (semi-anthracite) would be a consequence of its low reactivity, associated with higher ash content $(18.15 \%)$ : the inert material does not react in the gasification process and diminishes the process capacity to transform a solid fuel to a gaseous one.

Coal C3 (sub-bituminous B) displays a CCE 19\% higher in the dry process than that in the slurry process (Figure 4e and 4f), consistent with its higher $\mathrm{VM}$ and lower ash content, as well as the higher CO concentration in the syngas reached with the D-FT. Therefore, a higher amount of steam is required in the WGSR and thus SNG increases because increases the amount of reactants. Based on the GE, coals with higher $\mathrm{VM} / \mathrm{FC}$ ratio and low ash content (i.e., more reactive coals) lead to higher coal conversion in the thermochemical process. GE is also favored with slurry-feed technology. The best performance is reached by fuel with higher volatile content, such as C3, C10, C4 and C9.

The CCE is affected by the SNG volumetric flow rate, see equation 3. Figure 5a shows that $\mathrm{SNG}$ volumetric flow rate increases with $(\mathrm{C}+\mathrm{H}) / \mathrm{O}$ ratio, possibly due to the higher carbon and hydrogen present in the reaction. This trend would explain the relationship found between CCE and the elemental coal composition shown in Figure 4e. 
The SNG production rate tends to increase with $\mathrm{HHV}_{\text {coal }}$ (Figure $5 \mathrm{~b}$ ), as a consequence of the higher gaseous fuel concentration in the syngas that leads to larger amounts of steam required in the WGSR, to shift the $\mathrm{CO}$ to $\mathrm{H}_{2}$. Therefore, while increasing the amount of reactants an increment in the SNG production is obtained. The steam required in the WGSR is shown in Figure 5c.

As previously discussed, the amount of steam used in each scenario aims at achieving a molar ratio of $\mathrm{H}_{2}$ / $\mathrm{CO}=3.0$ in the syngas before the methanation stage to maximize the final $\mathrm{CH}_{4}$ concentration. The SNG production process with S-FT requires between 66.5 and $135 \mathrm{ton} / \mathrm{h}$ of steam, while the D-FT requires between 162 and 209.8 ton/h of steam. This difference is a consequence of the higher $\mathrm{CO}$ concentration in the D-FT $\left(\mathrm{CO} / \mathrm{H}_{2 \mid \text { syngas }}>3.0\right)$, while the S-FT produces higher concentration of $\mathrm{H}_{2}$ and $\mathrm{CH}_{4}(1.0<\mathrm{CO} /$ $\mathrm{H}_{2 \text { syngas }}<2.0$ ). In summary, it can be stated that better energy parameters in the SNG production process by means of coal gasification, can be achieved (in descending order of importance) with higher coal reactivity (higher $\mathrm{VM} / \mathrm{FC}$ and $\mathrm{C}+\mathrm{H} / \mathrm{O}$ ratios), lower ash content and higher $\mathrm{HHV}_{\text {coal }}$.

\section{Conclusions}

The effect of coal type and F-FT on the SNG production process has been evaluated in this study, by simulating ten Colombian coals from sub-bituminous to semianthracite. According to the results, the following conclusions can be drawn.

1. The CGE increases with $\mathrm{VM} / \mathrm{FC}$ ratio, due to high levels of coal conversion by higher reactivity. On the other hand, coals with higher ash content achieve lower SNG production because the syngas production capacity diminishes with higher inert material in coals.

2. Regarding methane content in the $\mathrm{SNG}, \mathrm{HHV}_{\mathrm{SNG}}$ and WI for the slurry and dry processes, no significant differences between the different types of coal were found. This is because the $\mathrm{H}_{2} / \mathrm{CO}$ ratio was set to 3.0 for all coals previous to the methanation stage. The largest variation in these parameters is around $3.0 \%$. The SNG produced by simulation meets the quality standards for Colombia NG and, therefore, can be directly transported by pipeline.
3. Coals $\mathrm{C} 1, \mathrm{C} 2, \mathrm{C} 4$ and $\mathrm{C} 9$ are highlighted by their higher heating value. They affect $\mathrm{HHV}_{\mathrm{SNG}}$ and WI favorably. Notwithstanding, these coals do not reach the higher yields by themselves. This is due to their lower reactivity associated with the $\mathrm{HHV}_{\text {coal }}$ (i.e., with fixed carbon content).

4. In terms of GE, PE, and CCE, S-FT is more efficient than D-FT for the SNG production, which may be ascribed to the better quality of the syngas produced by the slurry process (average concentration of $\mathrm{CH}_{4}$ is around 7 vol. \%, while this species is not present in the D-FT because of the absence of steam as a gasifying agent in this process). Additionally, the $\mathrm{CO} / \mathrm{H}_{2 \mid \mathrm{dry}}$ ratio in the syngas is higher than 3.0 (CO concentration in syngas exceeds $60 \% \mathrm{vol}$ ) while the slurry process produces higher $\mathrm{H}_{2}$ concentration in the syngas $(1.0<$ $\left.\mathrm{CO} / \mathrm{H}_{2 \mid \text { Slurry }}<2.0\right)$. Therefore, the better syngas quality associated with higher $\mathrm{H}_{2}$ and $\mathrm{CH}_{4}$ concentrations leads to increase the GE and PE.

5. The best energy parameters for the SNG production process by means of gasification are reached using coals with higher $\mathrm{VM} / \mathrm{FC}$ ratio, lower ash content, higher $(\mathrm{C}+\mathrm{H}) / \mathrm{O}$ ratio and higher $\mathrm{HHV}_{\text {coal }}$, in descending order of importance. The coals with better yields were: $\mathrm{C} 3$ (sub-bituminous B), C10 (high volatile $\mathrm{C}$ bituminous) and $\mathrm{C} 9$ (high volatile A bituminous). On the other hand, coals with lower energy performance, lower SNG conversion rate and lower SNG production (less than 80 MMCFD) are coals with higher ash contents, such as C5 (high volatile A bituminous), C6 (medium volatile bituminous) and $\mathrm{C} 7$ (semi-anthracite).

\section{AcKnowledgments}

The authors thank Celsia S.A. ESP and UdeA for the support to the project code PI12-1-05.

\section{REFERENCES}

[1] Unidad de Planeación Minero Energética, "Plan de Abastecimiento para el Suministro y Transporte de Gas Natural", Technicalreport, UPME, Ministerio de Minas y Energía, Bogotá, 2010.

[2] PROURE, Programa de uso raconal de la energía, "Plan de acción 2010-2015", Technical report, Ministerio de Minas y Energía, Bogotá, 2010. 
[3] F. A., Diaz, "The future challenges for clean coal technologies: Joining efficiency increase and pollutant emission control", Energy, vol. 34, pp. 348-354, 2009. DOI: http://dx.doi. org/10.1016/j.energy.2008.09.012.

[4] British Petroleum, "Statistical Review of World Energy", Technical report, BP, London, 2011.

[5] J.F. Pérez, R. Barrera, and C. Salazar, Producción de gas natural sintético mediante gasificción de carbones Colombianos. Medellín, Colombia: Ed. Universidad de Antioquia, 2015.

[6] M. de Souza-Santos, Solid Fuels Combustion and Gasification: Modeling, Simulation, and Equipment Operation, New York, NY, USA: Marcel Dekker Inc., 2004. DOI: http://dx.doi. org/10.1201/9780203027295.

[7] S. Cheng-Hsien, C. Wei-Hsin, H. Heng-Wen, S. Jieh-Yn andH. Tzu-Hsien, "Co-gasification performance of coal and petroleum coke blends in a pilot-scale pressurized entrained-flow gasifier", Int. J. Energ. Res., vol. 36, pp. 499508, 2012. DOI: http://dx.doi.org/10.1002/ er.1821.

[8] J. Tomeczek and S. Gil, "The kinetics of coal chars hydrogasification", Fuel Process. Technol., vol. 91, pp. 1564-1568, 2010. DOI: http://dx.doi.org/10.1016/j.fuproc.2010.06.003.

[9] A. Karcz and S. Porada, "The influence of coal rank on formation of gaseous hydrocarbons in hydrogasification of coal", Fuel, vol. 75, pp. 641-645, 1996. DOI: http://dx.doi. org/10.1016/0016-2361(95)00298-7.

[10] S. Lee, J. Kim and Y. Choi, "Hydrogasification characteristics of bituminous coals in an entrained-flow hydrogasifier", Fuel, vol. 85, pp. 803-806, 2006. DOI: http://dx.doi. org/10.1016/j.fuel.2005.08.039.

[11] O. Maurstad, H. Herzog, O. Bolland and J. Beér, "Impact of coal quality and gasifier technology on IGCC performance", Technical report, CC\&ST Program,Norwegian Research Council in the KLIMATEK program, 2013.

[12] Y. Yun, Y. Yoo andS. Chung, "Selection of IGCC candidate coals by pilot-scale gasifier operation", Fuel Process. Technol., vol. 88, pp. 107-116, 2007. DOI: http://dx.doi.org/10.1016/j. fuproc.2004.08.009.

[13] M. Gräbner and B. Meyer, "Performance and exergy analysis of the current developments in coal gasification technology", Fuel, vol. 116, pp. 910-920, 2014. DOI: http://dx.doi. org/10.1016/j.fuel.2013.02.045.
[14] C. Kunze and H. Spliethoff, "Modelling, comparison and operation experiences of entrained flow gasifier", Energ. Convers. Manage., vol. 52, pp. 2135-2141, 2011. DOI: http://dx.doi.org/10.1016/j. enconman.2010.10.049.

[15] R. Barrera, C. Salazar and J. F. Pérez, "Thermochemical Equilibrium Model of Synthetic Natural Gas Production from Coal Gasification Using Aspen Plus", Int. J. Chem. Eng., vol. 2014, Article ID 192057, 2014. DOI: http://dx.doi.org/10.1155/2014/192057.

[16] R. Barrera, C. Salazar, J. F. Pérez, "Carbones colombianos: clasificación y caracterización termoquímica para aplicaciones energéticas", Rev. ION, vol. 27, pp. 43-54, 2014.

[17] J. Longanbach, T. Buchanan, M. Klett and R. Schoff, "Capital and operating cost of hydrogen production from coal gasification", Technical Report, NETL - U.S. Department of Energy, 2003.

[18] A. Van der Drift, B. Coda, M. Cieplik and K. Hemmes, "Entrained Flow Gasification of Biomass. Ash behaviour, feeding issues, and system analyses", Technical Report, ECN, Netherlands, 2004.

[19] M. Öztürk, N. Özek and Y. E. Yüksel, "Gasification of various types of tertiary coals: A sustainability approach", Energ. Convers. Manage., vol.56, pp. 157-165, 2012. DOI: http:// dx.doi.org/10.1016/j.enconman.2011.11.008.

[20] D. Harris, D. Roberts and D. Henderson, "Gasification behaviour of Australian coals at high temperature and pressure", Fuel, vol. 85, pp. 134-142, 2006. DOI: http://dx.doi. org/10.1016/j.fuel.2005.07.022.

[21] S. Karellas, K. D. Panopoulos, G. Panousis, A. Rigas, J. Karl and E. Kakaras, "An evaluation of Substitute natural gas production from different coal gasification processes based on modeling", Energy, vol. 45, pp. 183-194, 2012. DOI: http:// dx.doi.org/10.1016/j.energy.2012.03.075.

[22] Comisión de Regulación de Energía y Gas (CREG), "Calidad en transporte de gas", Comisión Reguladora de Energía y Gas de Colombia, Resolución 017, Ministerio de Minas y Energía, 2007.

[23] J. Kim, H. Choi, J. Lim, Y. Rhim, D. Chun, S. Kim, S. Lee S and J. Yoo, "Hydrogen production via steam gasification of ash free coals", Int. J. Hydrogen Energ., vol. 38, pp. 60146020, 2013. DOI: http://dx.doi.org/10.1016/j. ijhydene.2012.12.058. 